\title{
TEISMINĖS VALDŽIOS KONSTITUCINĖ SAMPRATA LIETUVOJE IR LENKIJOJE
}

\begin{abstract}
Santrauka. Straipsnis skirtas išanalizuoti 1992 m. Lietuvos Respublikos ir 1997 m. Lenkijos Respublikos Konstitucijų nuostatų panašumus ir skirtumus, susijusius su teisminès valdžios konstituciniu statusu. Straipsnị sudaro trys dalys: I. Teisminės valdžios vieta Lenkijos ir Lietuvos konstitucijose, II. Lietuvos Konstitucinis Teismas ir Lenkijos Konstitucinis Tribunolas ir III. Speciali teisėjų institucija pagal Lietuvos Konstituciją ir Nacionalinė Teismų Tarybą pagal Lenkijos Konstituciją. Tyrimo pabaigoje teigiama, jog didele dalimi teisminès valdžios konstitucinis statusas abiejose konstitucijose yra labai panašus, bet galima išskirti šiuos skirtumus ir padaryti šiuos apibendrinimus: 1. Lenkijos Konstitucija numato karinius teismus, kurie nagrinejja krašto apsaugos ministerijos pareigūnų baudžiamąsias bylas, tuo tarpu Lietuvos Konstitucija tokių teismų nenumato. Be to, Lenkijos Konstitucija numato teisminès valdžios institucijų dvi rūšis: teismai ir tribunolai, įskaitant ir Konstitucinį Tribunolą. Tuo tarpu Lietuvos Konstitucija tribunolu nenumato, o konstitucinès priežiūros institucijos pavadinimas yra Konstitucinis Teismas. 2. Lietuvos Konstitucija numato dvejopą aukštesnių instancijų teismų teisèjų atleidimo būdą, kai pripažįstama, kad jie savo poelgiu pažemino teisèjo vardą: 1) paprastesniu būdu - Aukščiausiojo Teismo teisèją galima atleisti Seimo nutarimu, o Apeliacinio teismo teisèją - Prezidento dekretu arba 2) sudètingesniu būdu - šiems teisejjams galima taikyti apkaltos procesą Seime. Tuo tarpu Lenkijos Konstitucija apkaltos proceso atleisti teisejjams nenumato. 3. Lietuvos Konstitucinis Teismas ir Lenkijos Konstitucinis Tribunolas plačiąja prasme priklauso teisminei valdžiai, o šių konstitucinès priežiūros institucijų funkcijos iš esmès yra labai panašios, visgi, pagrindinis skirtumas galètų būti tas, kad ị Lenkijos Konstitucinį Tribunolą dėl teisès aktų abstrakčios konstitucinès kontrolès turi teisę kreiptis daug platesnis subjektų ratas nei į Lietuvos Konstitucinị Teismą. Iš kitos pusès, Lenkijos Konstitucinis Tribunolas neturi kompetencijos teikti išvadų dẻl pareigūnų veiksmų, kuriems pradètas apkaltos procesas bei dẻl rinkimų įstatymų pažeidimų. Pagaliau, pagal ordinarinę teisę bent vienas Lenkijos Konstitucinio Tribunolo narys ex officio eina ir Lenkijos Vyriausiosios rinkimų komisijos nario pareigas. 4. Nors Lenkijos Konstitucijoje Nacionalinei Teismų Tarybai yra skirtas gana didelis dẻmesys, tačiau šiuo metu Lietuvos Teisèjų Tarybos sprendimai turi didesnị konstitucinị svorị (nei Lenkijos Nacionalinès Teismų Tarybos), nes jos neigiamas patarimas dèl teisèjų skyrimo ar atleidimo ịpareigoja Lietuvos Respublikos Prezidentą neskirti ar neatleisti teisèjo. Be to, pagal Lietuvos Respublikos Teismų įstatymą, Lietuvos Teisèjų Tarybos nariais gali būti tik teisėjai, kurių didžioji dalis yra renkama Visuotiniame teisèjų susirinkime, tuo tarpu Lenkijos Teismų Tarybos nariais gali būti ne tik teisejjai, be to, teisejjai ị šias pareigas Lenkijoje nèra renkami pačios teisminès valdžios, o skiriami politikų.
\end{abstract}

Pagrindiniai žodžiai: Lietuvos Konstitucija, teisminė valdžia, teismų nepriklausomumas, Lietuvos Konstitucinis Teismas, Lenkijos Konstitucinis Tribunolas.

"Vilniaus universiteto, Teisès fakultetas, Viešosios teisès katedra, vaidotas.vaicaitis@tf.vu.lt. 


\title{
THE CONSTITUTIONAL CONCEPT OF JUDICIAL POWER IN POLAND AND LITHUANIA
}

\begin{abstract}
The article is intended to analyze similarities and differences of the 1992 Lithuanian Constitution and the 1997 Polish Constitution regarding the constitutional status of the judiciary. The article consists of three parts: I. The place of judicial power in the Polish and Lithuanian constitutions, II. Lithuanian Constitutional Court and Polish Constitutional Tribunal and III. A special institution of judges under the Constitution of Lithuania and the National Judicial Council under the Constitution of Poland. At the end of the article following differences are to be distinguished: 1 . The Polish Constitution mentions military courts, while in Lithuania they do not exist. In addition, the Polish Constitution provides for two types of judicial authorities: courts and tribunals, including the Constitutional Tribunal, meanwhile, the Lithuanian Constitution include only courts. 2. The Constitution of Lithuania provides for two methods of dismissal of judges of the Supreme Court, when they discredit the name of a judge: 1) by the resolution of the Seimas and 2) under impeachment proceedings. Meanwhile, the Polish Constitution does not mention the impeachment proceedings for dismissal of judges. 3. The Constitutional Court of Lithuania and the Constitutional Tribunal of Poland in broader sense belong to the judiciary, and the functions of these institutions are very similar, however, the main difference could be that there are more subjects to address the Polish Constitutional Tribunal than to the Lithuanian Constitutional Court. On the other hand, the Polish Constitutional Tribunal has no jurisdiction to rule on the actions of officials under impeachment and on violations of electoral laws. Finally, under ordinary law, at least one member of the Polish Constitutional Tribunal ex officio is also a member of the Polish Central Electoral Commission. 4. Although the Polish Constitution pays considerably more attention to the National Judicial Council, currently the decisions of the Lithuanian Judicial Council have a greater constitutional weight (than the Polish National Judicial Council), as its negative advice on the appointment or dismissal obliges the President of the Republic. In addition, according to the Law on Courts of the Republic of Lithuania, only judges, the majority of whom are elected by the General Assembly of Judges, may be members of the Lithuanian Judicial Council, while some members of the Polish Judicial Council are not members of judiciary, including those, appointed by politicians.

Keywords: Constitution, judiciary, independence of courts, Lithuanian Constitutional Court, Polish Constitutional Tribunal.
\end{abstract}

\section{KONSTYTUCYJNA KONCEPCJA WLADZY SĄDOWNICZEJ NA LITWIE I W POLSCE}

Streszczenie. Artykuł ma na celu analizę podobieństw i różnic Konstytucji Republiki Litewskiej z 1992 r. i Konstytucji Rzeczypospolitej Polskiej z 1997 r., związanych ze statusem konstytucyjnym władzy sądowniczej. Artykuł składa się z trzech części: I. miejsce władzy sądowniczej w konstytucjach Polski i Litwy, II. litewski Sąd Konstytucyjny i polski Trybunał Konstytucyjny oraz III. specjalna instytucja sędziowska zgodnie z Konstytucją Litwy oraz Krajowa Rada Sądownictwa zgodnie z Konstytucją Polski. Z przeprowadzonego badania wynika, że status konstytucyjny władzy sądowniczej w obu konstytucjach jest w dużej mierze podobny, można jednak wyodrębnić wskazane poniżej różnice i dokonać następujących uogólnień: 1. Konstytucja Polski przewiduje sądy wojskowe, które rozpoznają sprawy karne przeciwko funkcjonariuszom Ministerstwa Obrony Narodowej, podczas gdy Konstytucja Litwy nie przewiduje takich sądów. Ponadto, Konstytucja Polski określa dwa rodzaje organów sądowych: sądy i trybunały, w tym Trybunał Konstytucyjny. Tymczasem Konstytucja Litwy nie przewiduje trybunału, a instytucją nadzoru konstytucyjnego jest 
Sąd Konstytucyjny. 2. Konstytucja Litwy zakłada podwójny sposób odwoływania sędziów sądów wyższych instancji po uznaniu, że swoimi działaniami sprzeniewierzyli się godności sędziego: 1) sędzia Sądu Najwyższego może zostać odwołany uchwałą Sejmu, a sędzia sądu apelacyjnego - dekretem Prezydenta lub 2) sędziowie tych sądów mogą podlegać procedurze impeachmentu przed Sejmem. Tymczasem Konstytucja Polski nie przewiduje odwołania sędziów w drodze impeachmentu. 3. Sąd Konstytucyjny na Litwie i Trybunał Konstytucyjny w Polsce w szerokim sensie stanowią część władzy sądowniczej. Funkcje tych organów nadzoru konstytucyjnego są w zasadzie bardzo podobne, główna zaś różnica polega na tym, że znacznie szerszy krąg podmiotów ma prawo zwrócić się do Trybunału Konstytucyjnego w Polsce niż do Sądu Konstytucyjnego na Litwie o abstrakcyjną kontrolę konstytucyjną aktów prawnych. $Z$ drugiej strony, Trybunał Konstytucyjny w Polsce nie ma kompetencji do składania opinii dotyczących działań funkcjonariuszy, wobec których wszczęto procedurę impeachmentu oraz w sprawie naruszeń ustaw o ordynacji wyborczej. Wreszcie, zgodnie z prawem powszechnym co najmniej jeden członek Trybunału Konstytucyjnego w Polsce ex officio jest jednocześnie członkiem Państwowej Komisji Wyborczej. 4. Chociaż w Konstytucji Polski Krajowej Radzie Sądownictwa poświęcono dość dużo uwagi, to jednak w chwili obecnej uchwały Litewskiej Rady Sądownictwa mają większą wagę konstytucyjną (w porównaniu z Krajową Radą Sądownictwa), ponieważ jej negatywna opinia w sprawie powołania lub odwołania sędziów jest wiążąca dla Prezydenta Republiki Litewskiej. Ponadto, zgodnie z Ustawą Republiki Litewskiej o Sądach, tylko sędziowie, z których większość jest wybierana przez Walne Zgromadzenie Sędziów, mogą być członkami Litewskiej Rady Sądownictwa, podczas gdy nie tylko sędziowie mogą być członkami Krajowej Rady Sądownictwa w Polsce, ponadto sędziowie na to stanowisko w Polsce nie są wybierani przez przedstawicieli władzy sądowniczej, ale są powoływani przez polityków.

Słowa kluczowe: Konstytucja Litwy, władza sądownicza, niezawisłość sądów, Sąd Konstytucyjny na Litwie, Trybunał Konstytucyjny w Polsce.

\section{IVADAS}

Teisminès valdžios samprata konstitucinėje teisèje, atrodo, negalètų būti traktuojama, kaip turinti konstitucinès teisès mokslo tyrimo ir analizès deficitą. Šiai temai skirta daug dėmesio Lietuvos konstitucinès teisès vadovèliuose ir kituose moksliniuose rinkiniuose (pvz., Šileikis, 2005; Lietuvos teisinès institucijos, 2011; Nepriklausomos Lietuvos teise: praeitis, dabartis ir ateitis, 2012; Lietuvos konstitucinè teise், 2017). Literatūroje dažnai pabrèžiama, kad teisminė valdžia ir jos nepriklausomumas yra svarbus ne tik teisinès valstybès (ịskaitant valdžių padalijimą) bruožas, bet ir žmogaus teisių, visų pirma, teisès ị nešališką teismą ir nekaltumo prezumpciją, garantas. Kiek tai susiję su Lietuvos konstituciniais šaltiniais, jau anksčiau buvo pastebėtas paradoksas, kad konstitucinių šaltinių lygmenyje plačiausiai ir išsamiausiai teisminès valdžios teisinis statusas yra sureguliuotas XVI amžiaus Lietuvos Statutuose, ypač 1588 m. Trečiojo Lietuvos Statuto redakcijoje (žr. Lietuvos konstitucionalizmo istorija: Istorine Lietuvos Konstitucija. 1387 m.-1566 m.-1791 m.-1922 m.-1990 m. 2016). Tačiau šio straipsnio tikslas yra ne istorinis konstitucionalizmas, o teisminès valdžios nuostatos, įtvirtintos dabar galiojančiose 1992 m. Lietuvos Respublikos ir 1997 m. 
Lenkijos Respublikos konstitucijose. Aktualumą šiai temai suteike pastarųų metų diskusija dèl Lenkijos Nacionalinès Teisèjų Tarybos ir Konstitucinio Tribunolo nepriklausomybès (Matczak 2018), iš vienos pusès, bei Lietuvos Aukščiausiojo ir Apeliacinio teismo teisèjų atleidimo būdų, konstatavus nepriekaištingos reputacijos pažeidimą, iš kitos pusès. Minètos aktualijos sąlygojo šio straipsnio struktūrą: pirma dalis skirta bendrai teisminès valdžios konstitucinių nuostatų apžvalgai Lietuvos ir Lenkijos konstitucijose, antra dalis - abiejų konstitucinių teismų statusui, trečia - Lietuvos Teisejjų Tarybai ir analogiškai institucijai Lenkijoje - Nacionalinei Teismų Tarybai (jų statusui ir narių skyrimo tvarkai). Pagrindiniai šaltiniai, analizuojant Lenkijos teismų sistemą, šiame straipsnyje yra Lodzès Universiteto parengta Lenkijos konstitucinès teisès mokymo priemoné (Górecki red. 2012) ir atitinkama Boguslawo Banaszako studija anglų kalba (Banaszak 2006) bei Gintaro Kalinausko straipsnis (Kalinauskas 2012). Šiame straipsnyje daugiausiai naudoti analitinis ir lyginamasis tyrimo metodai. Šis straipsnis yra rezultatas kasmetinių Vilniaus Universitetų Teisès fakulteto ir Lodzès Universiteto Teisès ir administracijos fakulteto konstitucinès teisės seminarų.

\section{BENDRA KONSTITUCINIŲ NUOSTATŲ APŽVALGA IR TEISMINĖS VALDŽIOS VIETA LENKIJOS IR LIETUVOS KONSTITUCIJOSE}

Visų pirma, reikia pastebėti, jog Lenkijos ir Lietuvos konstitucinè tradicija turi bendrų istorinių šaknų. Čia turima omenyje $1791 \mathrm{~m}$. Konstitucija, kuri buvo priimta Abiejų Tautų Respublikos vadinamajame keturmečiame Seime (lenk. Sejm Czteroletni), veikusiame 1788-1792 metais. Po I Pasaulio karo atsikūrus atskiroms nepriklausomoms Lenkijos ir Lietuvos Respublikoms, po kelių metu (1921 m. Lenkijoje ir $1922 \mathrm{~m}$. Lietuvoje) abiejose valstybèse buvo priimtos nuolatinès demokratinès konstitucijos su parlamentinėmis valdymo formomis, tačiau faktinis jų galiojimo laikas buvo labai trumpas, t.y. iki 1926 metų, kai abiejose šalyse buvo ịvykdyti perversmai (Lenkijoje perversmas ịvyko $1926 \mathrm{~m}$. gegužès, o Lietuvoje gruodžio mėnesị), abejose valstybėse ịvedę autoritarinị rèžimą. Po perversmo Lietuvoje vykdomoji valdžia oktrojavo 1928 ir 1938 metu Konstitucijas, o Lenkijoje - 1935 metų Konstituciją, įteisinusias autoritarinị valdymo režimą. Po II Pasaulinio karo Lenkijos Liaudies Respublika išliko nepriklausoma, tačiau čia Sovietų Sąjunga primetė marionetinị šalies valdymą, kuris gyvavo iki pat 1989 metų demokratinių pokyčiu visame Vidurio ir Rytų Europos regione (Banaszak 2006, VIII-6). Tuo tarpu Lietuva 1944 metais buvo antrąkart okupuota Sovietų Sąjungos ir inkorporuota i jos sudètị bei nepriklausomybę atgavo tik 1990 metais kovo 11 dieną. Po minètų ịvykių Lietuva naują nuolatinę Konstituciją prièmé 1992 metais (neskaitant $1990 \mathrm{~m}$. kovo 11 d. Laikinojo Pagrindinio İstatymo), tuo tarpu Lenkija - 1997 metais 
(neskaitant $1992 \mathrm{~m}$. vadinamosios Mažosios konstitucijos). Beje, abiejų konstitucijų prièmimas buvo panašus: 1992 metų Lietuvos Konstitucija buvo parengta ir priimta Aukščiausiosios Tarybos - Atkuriamojo Seimo 1992 m. spalio 13 dieną, o $1992 \mathrm{~m}$. spalio 25 dieną ratifikuota piliečių referendume. Panašiai ir Lenkijos Konstitucija $1997 \mathrm{~m}$. balandžio $2 \mathrm{~d}$. buvo priimta bendroje abiejų parlamento rūmų sesijoje - Nacionalinèje Asamblejjoje (lenk. Zgromadzenie Narodowe) ir po to 1997 m. gegužès 25 d. ratifikuota piliečių referendume (Banaszak 2006).

Taigi, vertinant 1992 m. Lietuvos Konstitucijos ir 1997 m. Lenkijos Konstitucijos tekstus, pasakytina, jog abiejų šalių konstitucijų struktūra ir nuostatų turinys, ypač nuostatų, susijusių su valdymo forma, yra ganètinai panašios. Štai abiejų konstitucijų preambulès įvardina tam tikrus valstybių istorinius faktus ir vertybes, pirmieji skirsniai yra skirti pagrindiniams valstybės principams ir simboliams, vèlesni skirsniai, skirti žmogaus teisèms, parlamentui, prezidentui, teisminei valdžiai, vietos savivaldai ir kitiems santykiams bei baigiasi konstitucijos keitimo procedūra. Abiejų šalių konstitucijos ịtvirtina valdymo formą, artimą pusiau prezidentiniam režimui su tiesiogiai renkamu Respublikos Prezidentu (plg., Vaičaitis 2017, 195-208; 2019, 243-260). Kaip skirtumą galima išskirti Lenkijos Konstitucijos III skirsni, skirtą „teisès šaltiniams“ aptarti, kurio nèra Lietuvos Konstitucijoje. Taip pat įdomu yra tai, kad Lietuvos Konstitucijoje „vietos savivaldos" konstitucinės nuostatos patalpintos po teismų skirsnių, tuo tarpu Lenkijos Konstitucijos VII skirsnis „Vietos savivalda” yra patalpintas prieš VIII skirsni „Teismai ir Tribunolai”. Taip pat galima išskirti ir mažesnių skirtumų, pvz., Lenkijos Konstitucijoje ombudsmenui yra skirta daugiau dèmesio ir ịgaliojimų (čia numatytas ne tik Lietuvos Seimo Kontrolieriaus atitikmuo - Piliečių teisių ombudsmenas, bet ir Vaiko teisių ombudsmenas), be to, Lenkijos Konstitucijoje atskiras poskyris su trimis straipsniais skirtas Nacionalinei Radijo ir Televizijos Tarybai (Lietuvos Radijo ir Televizijos komiteto atitikmuo).

Atkreiptinas dèmesys ir ị tai, kad Lenkijos Konstitucija yra detalesnè (tai taikytina ir teisminès valdžios skirsniui), nes ji apima beveik 250 straipsnių, tuo tarpu Lietuvos Konstitucija turi 150 straipsnių. Be to, jei dabartinę Lenkijos Konstituciją sudaro vienas dokumentas, tai Lietuvos Konstituciją galima vadinti sudètine konstitucija, nes be pagrindinio $1992 \mathrm{~m}$. spalio $25 \mathrm{~d}$. Konstitucijos teksto ji apima ir keturis konstitucinius aktus: $1991 \mathrm{~m}$. Konstitucini įstatymą „Dèl Lietuvos valstybès”, 1992 m. Konstitucinį aktą „Dẻl Lietuvos Respublikos nesijungimo ị postsovietines Rytų sąjungas”, 1992 m. Konstitucinį ịstatymą „Dél Lietuvos Respublikos Konstitucijos ịsigaliojimo tvarkos" ir $2004 \mathrm{~m}$. Konstitucinį aktą „Dèl Lietuvos Respublikos narystės Europos sąjungoje”, kurie yra 1992 m. spalio 25 d. Lietuvos Respublikos Konstitucijos sudetine dalimi. Kitas skirtumas yra tas, kad Lenkijos Konstitucija nuo jos prièmimo 1997 metais praktiškai nebuvo keista (buvo keičiama tik du kartus: Dziennik Ustaw z 2006 r. Nr 200, poz. 1471; Dziennik Ustaw z 2009 r. Nr 114, poz. 946), tuo tarpu Lietuvos Konstitucija buvo 
keičiama net 8 kartus ${ }^{1}$. Pagaliau, būtina paminèti, jog svarbiausias Konstitucijos pakeitimas Lietuvoje yra jau minètas 2004 metų Konstitucinis aktas „Dèl Lietuvos Respublikos narystès Europos Sąungoje", tuo tarpu Lenkijos Konstitucija visai neturi nuostatų, susijusių su jos naryste Europos Sajungoje.

Visgi, grįžkime prie teisminès valdžios nuostatų abiejose konstitucijose, kurių analizei ir skirtas šis straipsnis. Visų pirma, i akis krenta tai, jog abiejose konstitucijose teisminei valdžiai yra skirtas atskiras skirsnis (Lietuvos Konstitucijos IX skirsnis, o Lenkijos Konstitucijos VIII skirsnis), todèl būtent šiuose skirsniuose ir randame daugiausiai konstitucinių nuostatų apie teismus. Tačiau svarbu paminèti ir tai, kad pirmąkart teismai abiejose Konstitucijose paminèti jau I skirsnyje (Lietuvos Konstitucijos 5-tame, o Lenkijos Konstitucijos 10-tame straipsnyje), skirtame valstybei ir jos pagrindiniams principams, kartu ir valdžių padalijimui, apibrèžti. Tuo parodoma, jog teismai ir teisminè valdžia yra vienas svarbiausių valstybès elementų.

Kitas įdomus pastebėjimas yra tas, jog teisminès valdžios paminëjimas yra nemažiau svarbus abiejų Konstitucijų ,žmogaus teisių” skirsniuose (Lietuvos atveju - tai II-IV skirsniai, o Lenkijos - II skirsnis). Šiuose skirsniuose teisminè valdžia yra įtvirtinta, kaip apsaugos priemonè nuo galimų neteisètų žmogaus teisių suvaržymų. Taigi, teismai šiame kontekste abiejose konstitucijose, visų pirma, siejami su apsauga tokių žmogaus teisių (beje, Lietuvos Konstitucijoje jos dažniausiai vadinamos neliečiamomis), kaip teisè ị asmens laisvę, teisẻ ị privatų gyvenimą ir būsto neliečiamumą, teisè kreiptis ị teismą, teisé ị nekaltumo prezumpciją ir nešališką teismą bei rinkimų teisè. Lenkijos Konstitucijoje teisminè valdžia (be kai kurių minètų teisių) taip pat siejami su nuosavybès teisès bei tėvystès (motinystės) teisių ribojimais. Šios abiejų konstitucijų nuostatos nereiškia, kad teismai negali ginti kitų konstitucinių (ir ordinarinių) žmogaus teisių, tačiau tai, kad vadinamosioms neliečiamoms žmogaus teisėms suteikiama ypatinga konstitucinè apsauga.

${ }^{1} 1996$ m. birželio 20 d. Konstitucijos 47 straipsnio pakeitimas, Žin. 1996, Nr. 64-1501 (panaikinta nuostata dèl draudimo įsigyti žemès nuosavybę juridiniams asmenims); $1996 \mathrm{~m}$. gruodžio 12 d. Konstitucijos 119 straipsnio pakeitimas, Žin. 1996, Nr. 122-2863 (savivaldybių tarybų narių igaliojimai pratęsti nuo dviejų iki trijų metų); $2002 \mathrm{~m}$. birželio 20 d. Konstitucijos 119 straipsnio pakeitimas, Žin. 2002, Nr. 65-2629 (dèl savivaldybių tarybų narių ịgaliojimų pratęsimo nuo trijų iki ketverių metų); $2003 \mathrm{~m}$. sausio $23 \mathrm{~d}$. Konstitucijos 47 straipsnio pakeitimas, Žin. 2003, Nr. 14-540 (dèl leidimo užsienio teisès subjektams ịsigyti žemès nuosavybę Lietuvoje); 2003 m. kovo 20 d. Konstitucijos 84 ir 118 straipsnių pakeitimo, Žin. 2003, Nr. 321316 (dèl prokuratūros didesnio savarankiškumo garantavimo); 2004 m. liepos 13 d. Konstitucijos 57 straipsnio pakeitimas, Žin. 2004, Nr. 111-4124 (dèl Seimo rinkimų datos spalio mènesio antrą sekmadienį nustatymo) ir tos pačios datos Konstitucinis aktas „Dèl Lietuvos Respublikos narystès Europos Sąjungoje”; 2006 m. balandžio 25 d. Konstitucijos 125 straipsnio pakeitimas, Žin. 2006, Nr. 48-1701 (dẻl išskirtinių Lietuvos banko igaliojimų vykdyti pinigų emisiją panaikinimo, Lietuvai įstojus i ES) ir 2019 m. kovo 21 d. Konstitucijos 106-107 straipsnių pakeitimas, TAR 2019-04-02, i. k. 2019-05330 (dèl individualaus konstitucinio skundo instituto įvedimo). 
Šiame kontekste įdomu pastebèti ir tai, jog abiejų Konstitucijų skirsniuose, reguliuojančiuose parlamento, Respublikos Prezidento bei vietos savivaldos kompetenciją nėra daug nuostatų, susijusių su teismine valdžia. Nežiūrint ị tai, visgi, svarbu pabrěžti, jog teisminès valdžios konstitucinis statusas sukonstruotas taip, kad pastaroji persmelkia praktiškai visą Konstituciją, o teisminė valdžia nėra paminèta tik tuose abiejų Konstitucijų skirsniuose, kurie susiję su Vyriausybe, „Valstybės kontrole” ir „Konstitucijos keitimu”. Be to, Lietuvos Konstitucija teisminès valdžios nesieja ir su XI skirsniu „Finansai ir valstybès biudžetas” bei XIII skirsniu „Užsienio politika ir valstybės gynimas”.

İdomu yra tai, kad Lenkijos Konstitucija įvardina ,užsienio teisminès valdžios organo"sprendimus (lenk. wniosek sadowego organu międzynarodowego, 55 str. 3 d.), tuo tarpu Lietuvos Konstitucija užsienio teismų veiklos ar jų sprendimų nemini. Be to, abiejose konstitucijose galima išskirti ir tam tikrus teismų (ar teisminès valdžios) požymius. Štai Lietuvos Konstitucijoje yra numatyta, kad teismas yra „,nepriklausomas ir bešališkas” (31 str.), jis vykdo teisingumą (109 str.), teismas igyvendina valstybinę valdžią ir veikia valstybès vardu (5 ir 109 str.), teismas bylas nagrinejja viešai ir valstybine kalba (117 str.). Panašūs teismo požymiai numatyti ir Lenkijos Konstitucijoje, tiesa, čia jis įvardijamas kaip ne tik nepriklausomas ir bešališkas, bet ir kaip kompetentingas (lenk. właściwy). Taip pat abiejose Konstitucijose teisminė valdžia siejama su teisèjų veikla, tiesa, Lenkijos Konstitucija numato ir visuomenès dalyvavimą teisingumo vykdyme (182 str.).

Taigi, čia galima būtų apibendrinti teisminei valdžiai skirtų skirsnių nuostatų nedidelius skirtumus abiejose konstitucijose. Visų pirma būtina pastebėti, jog Lenkijos Konstitucijos VIII skirsnis yra skirtas teismams ir tribunolams, ịskaitant ir Konstitucinị Tribunolą. Tuo tarpu Lietuvos Konstitucijoje Konstituciniam Teismui yra skirtas atskiras VIII skirsnis, o tribunolai, kaip specifine teisminès valdžios institucija, visai nenumatyti. Antra, Lenkijos Konstitucijos 175 straipsnis numato trijų rūšių teismus: bendrosios kompetencijos (lenk. sądy powszechne), administracinius (lenk. sady administracyjne) ir karinius teismus (lenk. sqdy wojskowe). Lietuvių skaitytojui būtų įdomu sužinoti, kad apygardų ir batalionų (lenk. sądy okregowe i garnizonowe) kariniai teismai Lenkijoje vykdo teisingumą, daugiausiai nagrinèdami baudžiamąsias bylas dèl nusikaltimų karių, tarnaujančių krašto apsaugos sistemoje ir organizacine prasme yra šios sistemos dalis. Tiesa, šių teismų teisminę priežiūrą vykdo Aukščiausiasis Teismas, o jų teisejjus skiria Teisingumo ministras, pasitaręs su Krašto apsaugos ministru (Banaszak 2006, VIII-36; Młynarska-Sobaczewska 2012, 163).

Tuo tarpu Lietuvos Konstitucija karinių teismų nenumato, be to, ji numato galimybę įsteigti ne tik administracinius teismus, bet ir „darbo, šeimos ir kitų kategorijų byloms nagrinèti specializuotus teismus". Trečia, Lietuvos ir Lenkijos Konstitucijos tiesiogiai nenumato teisminių instancijų skaičiaus, tačiau Lenkijos Konstitucijos 176 str. 1 dalyje yra įtvirtinta, jog turi būti „mažiausiai dvi instancijos", tuo tarpu Lietuvos Konstitucijos 111-112 straipsniuose 
išvardinant keturis bendros kompetencijos teismus kartu su specializuotais teismais, netiesiogiai ịtvirtinta bendra trijų instancijų teismų sistema, ịskaitant apeliacinę („Lietuvos apeliacinis teismas”) ir kasacinę („Lietuvos Aukščiausiasis Teismas") instancijas. Beje, kalbėdamas apie bendrosios kompetencijos teismus, tai netiesiogiai yra patvirtinęs ir Konstitucinis Teismas: štai 2006 m. kovo 28 d. Konstitucinio Teismo nutarime konstatuota, kad

iš Konstitucijos kylanti bendrosios kompetencijos teismų instancinė sistema suponuoja tai, kad „negalima nustatyti tokio teisinio reguliavimo [...], kuriuo būtų paneigta Lietuvos apeliacinio teismo, kaip apeliacinès instancijos teismo, ir (arba) Lietuvos Aukščiausiojo Teismo, kaip kasacinès instancijos teismo, konstitucinè prigimtis" (Valstybės žinios 2006, Nr. 36-1292).

Ketvirta, galime teigti, jog Lenkijos Konstitucijos 184 straipsnis numato savarankišką administracinių teismų sistemą su Vyriausiuoju administraciniu teismu priešakyje, tuo tarpu remiantis Lietuvos Konstitucijos 111 ir 112 straipsnių sistemine analize galima daryti išvadą, jog Lietuvoje administraciniai ir kiti specializuoti teismai (kurių teisejjus kartu su apylinkių ir apygardų teisejjais vienasmeniškai skiria Respublikos Prezidentas) neturètų sudaryti atskiros teismų sistemos, o turètų veikti kaip pirmos instancijos teismai, kurių sprendimus galima skųsti apeliacine tvarka apygardos ar Apeliaciniam teismui ir kasacine tvarka Aukščiausiajam teismui ${ }^{2}$. Penkta, pagal Lenkijos Konstituciją, Lenkijos Konstitucinio, Aukščiausiojo ir Vyriausiojo administracinio teismo teisejjai turi teisę patys išsirinkti kandidatus ị šių teismų pirmininko pareigas, ị kurias galutinai skiria Respublikos Prezidentas. Tuo tarpu Lietuvos Konstitucija tokio teisejjų savivaldos mechanizmo nenumato, tačiau Lietuvoje skiriant teisèjus didesnę galią (nei Lenkijoje) turi Teisèjų Taryba. Šešta, Lenkijos Konstitucija numato visuomenès dalyvavimą teisingumo vykdyme, tuo tarpu Lietuvos Konstitucija neturi analogiškos nuostatos. Septinta, Lenkijos teismuose egzistuoja teismo asesoriu (lenk. asesor sadowy) pareigybè bei

${ }^{2}$ İdomumo dèlei reikètų priminti, jog administraciniai teismai Lietuvoje pagal pirminès, t.y. 1999 metų redakcijos Administraciniu bylu teisenos įstatyma (Valstybės žinios 1999, Nr. 13308) buvo įsteigti kaip apygardos administraciniai teismai, Aukštesnysis administracinis teismas ir Lietuvos apeliacinio teismo Administracinių bylų skyrius, t. y. buvo vieningos teismų sistemos dalis. Tuo tarpu jau 2000-ųjų metų šio įstatymo redakcija numatè atskirą dviejų instancijų administracinių teismų sistemą su apygardos administraciniais teismais (pirmoji instancija) ir Lietuvos vyriausiuoju administraciniu teismu (apeliacinè instancija) priešakyje, turinčiu teisę formuoti vienodą administracinių teismų praktiką. Tokia instancinè administracinių teismų sistema Lietuvoje galioja ir pagal 2019 m. rugsèjo 19 dienos minèto ịstatymo redakciją (TAR 2019-10-01, Nr. 15587). Kaip ten bebūtų, Lietuvos Konstitucinis Teismas savo jurisprudencijoje konstitucionalizavo atskirą administracinių teismų sistemą su Lietuvos vyriausiuoju administraciniu teismu priešakyje, nors ir nepateikdamas tam jokių konstitucinių argumentų (Teismas tiesiog konstatavo, jog „šiuo metu pagal Konstituciją ir įstatymus Lietuvoje yra trys teismų sistemos”, kurios „organizaciniu ir administraciniu atžvilgiu [...] yra atskirtos"). Žr. Konstitucinio Teismo 2006 m. birželio 6 d. nutarimas. Valstybės žinios. 2006, Nr. 65-2400. Lietuvos teisès moksle šiuo metu yra nusistovèjusi nuomonè pritarti tokiai Konstitucinio Teismo jurisprudencijai dẻl atskiros administracinių teismų sistemos atitikimo Lietuvos Konstitucijai (žr. pvz. Žvaigždinienė, Danelienė 2015, 187-201). 
„baigusiuju kadencija teisejju”” (lenk. sędzia w stanie spoczynku) institutas, tiesa, abu šie institutai nèra numatyti Lenkijos Konstitucijoje, o ịtvirtinti ịstatymuose ${ }^{3}$.

Visgi, užbaigti šią straipsnio dalị norèčiau nuostatų dèl teisèjų atleidimo iš pareigu problematika. Visu pirma reikia pasakyti, kad abiejų šalių konstitucijos teisèjams suteikia imunitetą nuo baudžiamosios atsakomybès, kas turètų būti vertinama kaip vienas iš teismų ir teisėjų nepriklausomumo garantų. Tačiau Lenkijos Konstitucija (181 str.) numato, kad teisėjo laisvẻ gali būti suvaržyta tik teismo sprendimu, tuo tarpu pagal Lietuvos Konstitucijos 114 str 2 dalį, norint patraukti teisėją baudžiamojon atsakomybèn, būtina tam gauti Seimo (o tarp Seimo sesijų - Prezidento) sutikimą. Tačiau netgi davus tokị sutikimą, tai neturètų būti automatiškai vertinama, kaip pagrindas atleisti teisèją iš pareigų.

Abiejų šalių konstitucijos numato, jog teisejjus skiria Respublikos Prezidentas pasitaręs su Teismų ar Teisèjų taryba (arba jos pasiūlymu), tačiau Lietuvoje, norint paskirti, taigi, ir atleisti aukštesnių instancijų teisejjus būtinas bendras Prezidento ir Seimu sutarimas. Taip pat įdomu yra tai, jog Lenkijos Konstitucija neịvardina teisėjo atleidimo iš pareigų konkrečių pagrindų (paveda tai įstatymui), tuo tarpu Lietuvos teisejų atleidimo iš pareigų pagrindų baigtinis sąrašas yra įvardintas Konstitucijos 115 straipsnyje, o vienas iš jų yra teisèjo vardo pažeminimas.

Tačiau įdomu yra ir tai, kad Lietuvos Konstitucija (74 str. ir 116 str.) numato ir alternatyvų Aukščiausiojo ir Apeliacinio teismo teisejų atleidimo iš pareigų būdą - tai apkaltos procesas Seime. I tai atkreipé dèmesị ir kai kurie Lietuvos konstitucinès teisès mokslininkai (Vainiute 2012, 699), tuo tarpu Lenkijos Konstitucijoje apkaltos procesas nėra numatytas. Teisybės dèlei pasakytina, kad minètas teisejų atleidimas apkaltos proceso tvarka Lietuvos Konstitucijoje vadinamas „pašalinimu” iš pareigų“, be to, jame kiek skirtingai ịvardinti teisèjo pašalinimo pagrindai, t. y. šiurkštus Konstitucijos pažeidimas arba priesaikos sulaužymas, taip pat paaiškèjimas, jog padarytas nusikaltimas. Todèl galima teigti, jog konkretūs teisèjo veiksmai kartais gali būti laikomi ir „teisèjo vardo pažeminimu“ (pagal Konstitucijos 115 str. 5 p.) ir tuo pačiu - „šiurkščiu Konstitucijos pažeidimu arba priesaikos sulaužymu” (74 str. ir 116 str.). Todẻl Lietuvos Respublikos Seimas, gavęs Prezidento teikimą dèl Aukščiausiojo ar Apeliacinio teismo teisẻjo atleidimo turi teisę apsispręsti, kurią teisejjo teisinès atsakomybès rūši pasirinkti: paprastesnę ar sudètingesnę, t. y. spręsti dèl teisejo atleidimo iš pareigų (pritariant ar nepritariant Prezidento teikimui) arba siekti teisèjo pašalinimo, pradedant jo atžvilgiu daug ilgesnę ir sudètingesnę - apkaltos procedūrą.

Tiesa, Lietuvos teisès mokslininkų tarpe yra ir tokia nuomonè, kad Lietuvos Aukščiausiojo ir Apeliacinio teismo teisèju ,,veikiausiai“ negalima atleisti iš pareigu

${ }^{3}$ Abu institutai numatyti Lenkijos Bendrosios kompetencijos teismu santvarkos istatyme ir Administraciniu teismu santvarkos istatyme. Teismo asesorius penkerių metų laikotarpiui skiria Respublikos Prezidentas Nacionalinės Teismų Tarybos teikimu., žr. Prawo o ustroju sądów powszechnych oraz niektórych innych ustaw (Dz. U. z 2015 r., poz. 1224) ir Prawo o ustroju sądów administracyjnych (Dz. U. z 2019 r., poz. 2167). 
pagal Konstitucijos 115 straipsnio 5 punkte nurodytą pagrindą (t. y. už teisėjo vardo pažeminimą), kitaip tariant, juos pašalinti iš pareigų galima būtų tik apkaltos proceso tvarka pagal Konstitucijos 116 straipsnị (Butkevičius, Kūris, Šinkūnas 2011, 180). Tačiau su tokia nuomone sutikti būtų sunku, nes jei Aukščiausiojo ir Apeliacinio teismo teisejams yra taikomi visi kiti 115 straipsnio punktuose $(1,2,3$, 4 ir 6) nurodyti teisèjų atleidimo iš pareigų pagrindai, būtų neaišku, kodèl jiems, neturètų būti taikomas 5 punktas dẻl jų atleidimo ,pažeminus teisẻjo vardąa“? Tiesa, Konstitucijos 112 straipsnyje nėra nurodyta Apeliacinio teismo teisèjų atleidimo tvarka, tačiau, kadangi šiame straipsnyje nurodyti visų kitų teismų (Aukščiausiojo, apylinkių, apygardų ir specializuotų teismų) teisèjų atleidimo iš pareigų subjektai yra tokie pat, kaip ir paskyrimo, todèl „veikiausiai” pagal Lietuvos Konstituciją, Apeliacinio, kaip ir Aukščiausiojo teismo teisèjus už teisėjo vardo pažeminimą gali atleisti iš pareigu juos paskyrę subjektai (t.y. priėmus Prezidento dekretą ar Seimo nutarimą) arba Seimas juos gali pašalinti iš pareigų apkaltos proceso tvarka, jei teisèjo vardo pažeminimą galima būtų perkvalifikuoti ị šiurkštų Konstitucijos pažeidimą ir/ar priesaikos sulaužymą.

\section{LIETUVOS KONSTITUCINIS TEISMAS IR LENKIJOS KONSTITUCINIS TRIBUNOLAS}

Modernaus konstitucionalizmo Europoje vienas pagrindinių bruožų yra specialios konstitucinès priežiūros (kontrolès) institucijos egzistavimas. İdomu pastebėti, jog ne visose valstybėse, kur tokia institucija egzistuoja, ji yra priskiriama teisminei valdžiai, kaip kad Prancūzijos Konstitucinė Taryba. Tuo tarpu, kaip matysime vèliau, tiek Lenkijoje, tiek ir Lietuvoje šios institucijos yra teisminès valdžios dalis. Nežiūrint šių abiejų valstybių konstitucinės priežiūros institucijų principinio panašumo ị vadinamąjį Kelseno modelį, visgi, Lenkijos Konstitucinio Tribunolo statusas labiau panašus i Ispanijos Konstitucinio Tribunolo statusą, tuo tarpu Lietuvos Konstitucinio Teismo statusas panašesnis i Italijos Konstitucinio Teismo statusą (bent jau taip buvo iki $2019 \mathrm{~m}$. Konstitucijos Pataisos, kuri įvede Lietuvoje individualų konstitucinị skundą. Žr. TAR 201904-02, 2019-05330). Čia taip pat būtina pasakyti, kad Lenkijos Konstitucinis Tribunolas veikia nuo 1986 metų, taigi, jo jurisprudencija (visų pirma po 1989 metų) neabejotinai prisidejo prie šiuolaikinès Lenkijos Konstitucijos sukūrimo (Michalak 2016, 104) ${ }^{4}$, tuo tarpu Lietuvos Konstitucinis Teismas pradejo veikti 1993 metais, taigi, jau po $1992 \mathrm{~m}$. Konstitucijos priemimo. Nors

${ }^{4}$ Lenkijos Konstitucinis Tribunolas buvo ịsteigtas $1985 \mathrm{~m}$. balandžio 29 d. įstatymu po 1982 m. kovo 26 d. Konstitucijos Pataisos, pakeitusios 1952 m. Lenkijos Liaudies Respublikos Konstituciją. Pagal ši ịstatymą, tam kad įsigaliotų Lenkijos Konstitucinio Teismo sprendimai, beveik visais atvejais juos turëjo patvirtinti tuometinis parlamentas (o faktiškai - Komunistų partija). Nežiūrint šio apribojimo (kuris, beje, išliko iki pat 1997 m. Konstitucijos prièmimo), 
po minètos 2019 metu kovo 21 d. Lietuvos Respublikos Konstitucijos Pataisos (ịvedus Lietuvoje individualaus konstitucinio skundo institutą) ịsigaliojimo abiejų šalių konstitucinès priežiūros institucijų kompetencija supanašèjo, tačiau išliko ir tam tikri skirtumai, kuriuos čia pamėginsime aptarti.

Lyginant šias institucijas, visų pirma, ,ị akis krenta” jų pavadinimų skirtumai: Lietuvoje konstitucinès priežiūros institucija vadinama teismu, tuo tarpu Lenkijoje - tribunolu. Čia reikia pastebèti, jog lyginamoji konstitucinè teisè išskiria tris specialių konstitucinès priežiūros institucijų pavadinimus: konstituciniai teismai, konstituciniai tribunolai ir konstitucinès tarybos. Pirmąji institucijos titulo modelị, kuris yra plačiausiai paplitęs, santykinai galima vadinti austro-vokišku (pagal 1920 m. Austrijos ir 1949 m. Vokietijos Pagrindini İstatymą), antrąji - lenkišku (pagal $1997 \mathrm{~m}$. Lenkijos Konstituciją) $)^{5}$ ir trečiajji - prancūzišku (pagal 1958 m. Prancūzijos Konstituciją). Konstitucinio teismo ir konstitucinès tarybos tradiciniai skirtumai yra du: a) „konstitucinis teismas" paprastai vykdo a posteriori (paskesniąją) konstitucingumo kontrolę, tuo tarpu „konstitucinè taryba" - a priori (išankstinę) konstitucingumo kontrolę (tiesa, po 2008 metų Prancūzijos konstitucinès reformos Prancūzijos Konstitucinè Taryba vykdo ir paskesniosios konstitucinès priežiūros funkcijas (JORF n ${ }^{\circ} 0171 \mathrm{du}$ 24 juillet 2008, page 11890 , texte $n^{\circ} 2$ )) ir b) konstitucinè taryba paprastai nèra laikoma teisminès valdžios dalis, o jos nariai nèra vadinami teisėjais. Tuo tarpu konstitucinio teismo ir konstitucinio tribunolo titulo vartojimo skirtumus konstitucinès priežiūros institucijos pavadinime būtų sunkiau ịvardinti, nes, kaip matysime vèliau, Lenkijos Konstitucinis Tribunolas yra teisminès valdžios dalis, o jo nariai yra vadinami teisejjais. Be to, kai kuriose kalbose (pvz., ispanų ar portugalų) „tribunolo” terminas yra bendrinis žodis, kaip tik įvardijantis teismą.

Tačiau, nesureikšminant konstitucinès priežiūros institucijų pavadinimų, pereikime prie Lenkijos ir Lietuvos Konstitucijos teksto. Galbūt paradoksalu, bet Lenkijos Konstitucijoje Konstitucinio Tribunolo statusui apibrežti yra skirtas bendras VIII skirsnis „Teismai ir Tribunolai”, kurio pradžioje įvardijami bendrieji, specializuoti ir kariniai teismai, o skirsnio paskutinès nuostatos skirtos Konstituciniam Tribunolui ir Valstybès Tribunolui (lenk. Trybunat Stanu) ${ }^{6}$. Iš viso to galima daryti išvadą, kad Konstitucinis Tribunolas Lenkijoje nedviprasmiškai priskiriamas teisminei valdžiai, o tai patvirtina ir Lenkijos Konstitucijos 10 straipsnis, kuriame kaip tik ir teigiama, jog „teisminę valdžią ịgyvendina teismai ir tribunolai”. Taigi, pagal Lenkijos Konstituciją, Konstitucinis Tribunolas

Lenkijos Konstitucinis Tribunolas, ypač po 1989 metų išplètojo gana plačią jurisprudenciją, kuri turèjo įtakos modernios $1997 \mathrm{~m}$. Konstitucijos tekstui.

${ }^{5}$ Reikia pasakyti, kad tiek Ispanijoje, tiek ir Portugalijoje konstitucinès priežiūros institucija taip pat vadinama Konstituciniu Tribunolu, tačiau šių šalių konstitucijose „tribunolas“ yra bendrinis teisminès valdžios terminas.

${ }^{6} \breve{S}$ ią Lenkijos instituciją, beje, galima vadinti specialiu ad hoc apkaltos organu pagal prancūzišką Valstybès Teisingumo Teismo (pranc. La Cour de justice de la République) modelị. 
yra teisminès valdžios dalis, nežiūrint ị tai, jog teisingumo vykdymas šiai konstitucinès priežiūros institucijai pagal Lenkijos Konstituciją (žr. 175 straipsnị) nèra priskirtas. Iš to galima daryti išvadą, kad Lenkijoje teisminès valdžios funkcijos nèra išimtinai susijusios su teisingumo vykdymu, bet jai priskiriamos ir kitos su tuo susijusios kompetencijos, t.y. konstitucinè priežiūra ir aukščiausių valstybès pareigūnų apkaltos procesas.

Tuo tarpu Lietuvos Konstitucijos tekste negalètume rasti tiesioginio atsakymo, ar Lietuvos Konstitucinis Teismas yra teisminès valdžios dalis, nežiūrint ị tai, kad Lietuvos Respublikos Konstitucinio Teismo įstatymo 1 straipsnyje teigiama, jog "Konstitucinis Teismas - teisminè institucija" (Valstybės žinios 1993, Nr. 6-120). Štai Konstitucijos 5 straipsnis, kuris įtvirtina valdžiu padalijimo principą, nurodo, jog „Valstybės valdžią Lietuvoje vykdo [...] Teismas”, o Konstitucijos IX skirsnis su analogišku pavadinimu („Teismas”) reguliuoja bendrosios kompetencijos ir specializuotų teismų statusą. Dar daugiau, Konstitucinio Teismo kompetencijai atskleisti Lietuvos Konstitucijoje (skirtingai nuo Lenkijos Konstitucijos) yra skirtas atskiras VIII skirsnis „Konstitucinis Teismas”, kuriame, beje, taip pat nèra minimos teisingumo vykdymo funkcijos. Galbūt dèl šių priežasčių, skiriant Lietuvos Konstitucinio Teismo teisèjus, Teisėjų tarybos (Respublikos Prezidentui patarianti speciali teisèjų institucija) vaidmuo Konstitucijoje nèra numatytas, kaip, beje, Konstitucinio Teismo teisèjai nedalyvauja ir teismų savivaldoje apskritai.

Tačiau, iš kitos pusès, Konstitucinio Teismo priskyrimui teisminei valdžiai pagal Lietuvos Konstituciją pasitarnauja pats šios institucijos pavadinime vartojamas „Konstitucinio Teismo” terminas. Be to, Konstitucinio Teismo ryšys su teismine valdžia atskleistas ir Lietuvos Konstitucijos 110 straipsnio nuostatoje, ịpareigojančioje bendrosios kompetencijos ir specializuotus teismus kreiptis ị Konstitucinị Teismą, esant abejonei dèl įstatymo ar kito teisès akto konstitucingumo. Be to, $2019 \mathrm{~m}$. Konstitucijos Pataisa net ir kiekvienam asmeniui suteikè teisę Konstituciniam Teismui pateikti konstitucinį skundą, išnaudojus visas teisinès gynybos priemones teismuose.

Kaip ten bebūtų, Lietuvos Konstitucinis Teismas, šiuo konkrečiu klausimu pasisakė 2006 m. birželio 6 dienos nutarime (Valstybės žinios 2006, Nr. 65-2400). Abejonè Seimo nariu grupei dèl Konstitucinio Teismo priskyrimo teisminei valdžiai greičiausiai kilo dèl to, kad šis Teismas nenagrinëja civilinių, baudžiamųjų ar administracinių bylų ir turi igaliojimus pašalinti iš teisinès sistemos Seimo priimtus teisès aktus (jau nekalbant apie ịgaliojimus valstybès pareigūnų apkaltos procese), o tai visuomet yra politiškai labai jautrūs klausimai. Kaip ten bebūtų, Konstitucinis Teismas šiame nutarime išskyrè bent tris argumentus, leidžiančius Konstitucini Teismą priskirti teisminei valdžiai, t.y. tai, kad jis a) vykdo teisès aktų konstitucingumo kontrolę, b) turi teisę aiškinti Konstituciją, c) šio Teismo teisejjais skiriami asmenys, turintys teisinị išsilavinimą ir ne mažesnị kaip 10 metų teisinio ar mokslinio pedagoginio darbo pagal teisininko specialybę stažą. Taigi, 
šiame nutarime buvo konstatuota, jog Konstitucinis Teismas pagal Konstituciją yra teismų sistemų dalis, nors ir turintis ypatingą statusą.

Visgi, tas argumentas, kad Konstitucinis Teismas vykdo teisès aktų konstitucingumo kontrolę (kai kuriose šalyse tokią kontrolę vykdo parlamentai ar konstitucinès tarybos), o pretendentams ị jo teisejjus taikomas teisinio išsilavinimo ir teisinio darbo stažo reikalavimas (toks reikalavimas taikomas ir kai kurioms neteisminių institucijų nariams, pvz., VRK nariams, Seimo kontrolieriams ir kt.), pats savaime nepriskiria Konstitucinio Teismo teisminès valdžios sistemai.

Todèl manytina, jog (kaip jau buvo minèta) pagrindinis argumentas, kodèl Lietuvos konstitucinès priežiūros instituciją galètume priskirti teisminei valdžiai, yra jos pavadinime esantis terminas teismas ir tai, kad ši teismą sudaro ne šiaip nariai (kaip pvz. Prancūzijos Konstitucinèje Taryboje), o būtent teisejjai. Pagaliau, šis argumentas galètų būti dar labiau sustiprintas Lietuvos Konstitucijos 104 straipsnio nuostata, kad „Konstitucinio Teismo teisejjams taikomi darbo ir politinès veiklos apribojimai, nustatyti teismu teisejams".

Taigi, konstatavus, kad tiek Lenkijos Konstitucinis Tribunolas, tiek ir Lietuvos Konstitucinis Teismas yra teisminès valdžios dalis, visgi, būtina pabrezžti jų vadinamąji dvigubą konstitucinį statusą. Kitaip tariant, iš vienos pusès konstituciniai teismai yra teisminès valdžios dalis, o iš kitos pusès bet kuris konstitucinis teismas paprastai turi ir steigiamosios galios kompetenciją, nes turi ịgaliojimus aiškinti Konstituciją, atskleidžiant jos nuostatų prasmę, t.y. "kalbèti" steigiamojo dokumento - Konstitucijos vardu. Kadangi Konstitucija yra steigiamosios galios dokumentas, todèl tiek Lietuvos Konstitucinis Teismas, tiek ir Lenkijos Konstitucinis Tribunolas nėra tik paprasta teisminès valdžios institucija, veikianti Konstitucijos nustatytuose valdžių padalijimo rẻmuose, tačiau turi igaliojimus įvardinti, kokie yra tie valdžių padalijimo rẻmai ir koks apskritai yra Konstitucijos turinys, įskaitant ir savo paties konstitucinį statusą.

Pagaliau šios dalies pabaigoje galima būtų ịvardinti kai kuriuos abiejų šalių konstitucinès priežiūros institucijų igaliojimų skirtumus. Visų pirma, ,i akis krenta" tai, jog Lenkijos Konstitucinis Tribunolas neturi igaliojimų apkaltos (aukščiausių valstybès pareigūnų pašalinimo iš pareigų) procese, kaip kad Lietuvos Konstitucinis Teismas. Be to, Lenkijos Konstitucinis Tribunolas neturi igaliojimu teikti išvadų, ar nebuvo pažeisti rinkimų įstatymai per Seimo ir Prezidento rinkimus bei išvados, ar Respublikos Prezidento sveikatos būklẻ leidžia jam/jai eiti pareigas. Iš kitos pusės, Lenkijos Konstitucijos 188-189 straipsniai numato, jog Lenkijos Konstitucinis Tribunolas turi kompetenciją spręsti ginčus tarp centrinių valstybės organų, tirti ịstatymų ir centrinių valstybės organų teisès aktų atitikimą ratifikuotoms tarptautinėms sutartims bei tirti politinių partijų veiklos atitikimą Konstitucijai. Lietuvos Konstitucinis Teismas analogiškų igaliojimų neturi. İdomu pastebèti ir tai, jog ị Lenkijos Konstitucinị Tribunolą dèl teisès aktų abstrakčios konstitucingumo kontrolès gali kreiptis daug platesnis subjektų ratas: Nacionalinė Teismų Taryba, vietos savivaldos organai, nacionalinès darbuotojų profesinès 
sąjungos ir darbdavių konfederacijos, bažnyčios bei religinès organizacijos. Taip pat atkreiptinas dèmesys ị tai, kad Lenkijos Konstitucini Tribunolą sudaro 15 teisèjų (o ne 9 teisejjai, kaip Lietuvoje), o Tribunolo pirmininką ir vicepirmininką skiria Respublikos Prezidentas, remiantis paties Konstitucinio Tribunolo teisejų siūlymu. Pagaliau svarbu pastebėti ir tai, jog jei Lietuvos Konstitucinio Teismo teisejjai gali būti pašalinti iš pareigų tik apkaltos proceso tvarka Seime, tai Lenkijos Konstitucinio Tribunolo teisėjai anksčiau laiko gali būtų pašalinti iš pareigų tik pačių Konstitucinio Tribunolo teisèjų sprendimu. Tokia pozicija seka iš Lenkijos Konstitucijos 196 straipsnio, be to, ji detalizuota 2016 m. lapkričio 30 d. Lenkijos Respublikos Konstitucinio Tribunolo teiseju ų statuso įstatymo 18 straipsnyje (Žr. Ustawa z dnia 30 listopada 2016 r. o statusie sędziów Trybunału Konstytucyjnego. Dziennik Ustaw z 2018 r., poz 1422). Šios dalies pabaigoje galima paminèti dar vieną įdomų Lenkijos Konstitucinio Tribunolo teisejų statuso ypatumą, t. y. tai, kad pagal Lenkijos Rinkimų Kodeksą (t.y. pagal ordinarinị reguliavimą), Konstitucinio Tribunolo pirmininkas skiria vieną šio Tribunolo teisejją Vyriausiosios rinkimų komisijos (lenk. Państwowa Komisja Wyborcza) nariu (Rakowska-Trela 2018, 19)7.

\section{SPECIALI TEISĖJŲ INSTITUCIJA PAGAL LIETUVOS KONSTITUCIJĄ IR NACIONALINĖ TEISMŲ TARYBĄ PAGAL LENKIJOS KONSTITUCIJĄ}

Teismu savivalda paskutiniu metu susilaukia vis didesnio démesio konstitucinès teisès mokslininkų tarpe (Masnevaitè, Šinkūnas 2011, 147-152; Šinkūnas, Butkevičius 2011, 215-245; Beinoravičius, Vainiutė 2017, 573-579). Absoliučioje daugumoje ES šalių yra įsteigtos vadinamosios Teismų tarybos, kurių pagrindinis uždavinys yra garantuoti teismų ir teisejjų nepriklausomumą, ypač užtikrinti, kad teisėjų paskyrimai būtų vykdomi laikantis profesionalumo ir nepriekaištingos reputacijos principų. Haroldas Šinkūnas teigia, jog tokių institucijų nėra tik penkiose ES valstybėse: Austrijoje, Vokietijoje, Latvijoje, Suomijoje ir Čekijoje (Šinkūnas 2012, 206). Tuo tarpu MRU išleistame Lyginamosios konstitucinès teisės vadovėlyje pristatomos įvairių ES (Ispanijos, Italijos, Prancūzijos, Graikijos) teismų tarybų kompetencija ir sudètis, iš kurios aiškejja, kad jų nariais paprastai yra ne tik teisėjai, nors pastarieji paprastai sudaro daugumą; be to, čia pažymima ir tai, kad jų nariai dažniausiai skiriami mišriu būdu: dalị teismų tarybų narių renka patys teisèjai, o kitą dalị skiria vykdomoji ir/ ar ịstatymų leidžiamoji valdžia (Vaitiekienè 2016, 487-488).

${ }^{7}$ 2017-2018 m. buvo priimtos Lenkijos Rinkimų įstatymo kodekso pataisos, pagal kurias vieną Lenkijos VRK narị iš Konstitucinio Tribunolo teisejų skiria Tribunolo pirmininkas, dar vieną - iš Vyriausiojo administracinio teismo skiria šio teismo pirmininkas, o kitus septynis VRK narius skiria Seimas iš asmenų, galinčių užimti teisėjo pareigas. 
Jau buvo minèta, jog Lenkijos Konstitucija, skirtingai nei Lietuvos, įvardina trijų rūšių teismus: bendruosius (bendrosios kompetencijos), administracinius ir karinius teismus, kurių teisejjai ir dalyvauja bendroje teismų savivaldos sistemoje. Taip pat minèta, jog Lietuvos Konstitucija nepateikia „specializuotu teismų" baigtinio sąrašo, o teigia, kad Lietuvoje gali būti specializuoti teismai „administracinių, darbo, šeimos ir kitu kategoriju byloms nagrinèti”. Tiesa, Lietuvoje, kaip ir Lenkijoje, šiuo metu veikia tik bendrosios kompetencijos ir administraciniai teismai (aišku, neatmetama galimybẻ ateityje čia įsteigti ir kitu specializuotų teismų, jei ịstatymų leidèjas matytų tokią būtinybę), kurie dalyvauja Teisèjų Tarybos ir kitų teismų savivaldos organų veikloje.

Taip pat čia būtina pastebėti, jog nei Lenkijos Konstitucinis Tribunolas, nei Lietuvos Konstitucinis Teismas teismų savivaldoje nedalyvauja. Tam pagrịsti galima būtų remtis tuo, kad „speciali teisèjų institucija”, kaip pagrindinis teismų savivaldos organas, numatytas Lietuvos Konstitucijos IX skirsnyje "Teismas" - nèra minimas VIII skirsnyje „Konstitucinis Teismas”. Tuo tarpu Lenkijos atveju tai galima būtų pagrịsti tuo, jog Konstitucinis Tribunolas (lenk. Trybunat Konstytucyjny) nėra teismas (lenk. sąd) siaurąja šio žodžio prasme, todèl ir nedalyvauja Konstitucijos 186-187 straipsniuose minimos Teismu tarybos (lenk. Krajowa Rada Sadownictwa) veikloje.

Čia taip pat reikia priminti, jog Lietuvos Konstitucijoje (skirtingai nei Lenkijos) konkretus teisminès valdžios savivaldos organo pavadinimas nèra ìvardintas, o vartojamas abstraktesnis terminas „speciali teisejjų institucija”, pabrèžiantis ne teismu (kaip yra Lenkijoje), o teisèjų vaidmeni joje. Visgi, Lietuvoje pagal Teismu įstatymo pirminę, t.y. $1994 \mathrm{~m}$. gegužès $31 \mathrm{~d}$. redakciją (Valstybės žinios 1994, Nr. 46-851), ši institucija vadinosi Teiséjų taryba, vẻliau, prièmus 2002 m. sausio 24 d. įstatymo pataisą (Valstybès žinios 2002, Nr. 17-649), ji buvo pervadinta ị Teismu taryba ir pagaliau vèl - nuo $2006 \mathrm{~m}$. gegužès $23 \mathrm{~d}$. Teismų i̊statymo pataisos (Valstybès žinios 2006, Nr. 60-2121), padarytos po $2006 \mathrm{~m}$. gegužès $9 \mathrm{~d}$. Konstitucinio Teismo nutarimo, vèl sugrịžta prie Teisèjų tarybos termino, kuris, manytina, labiau atitinka Lietuvos Konstitucijos 112 str. 5 dalies terminą, „speciali teisèjų institucija”.

Visgi, lyginant pagrindinès teismų savivaldos ir nepriklausomumo garantijos institucijos, t.y. Teisejų tarybos Lietuvoje ir Nacionalinès Teismų Tarybos Lenkijoje konstitucinį statusą, galima pastebèti tai, jog Lietuvos Konstitucijoje apie ją tik nežymiai užsimenama, tuo tarpu Lenkijos Konstitucijoje jai skiriami net du atskiri specialūs straipsniai: 186 straipsnyje teigiama, jog Nacionalinè Teismų Taryba užtikrina teismų ir teisėjų nepriklausomą be tai, kad ji turi teisę kreiptis ị Konstitucinị Tribunolą dèl norminių aktų konstitucingumo (ta apimtimi, kuria jie susiję su teismų ir teisèjų nepriklausomumu), o 187 straipsnyje numatyta Nacionalinès Teismų Tarybos narių skaičius (25), jos sudetis, kadencijos trukmé (4 metais) ir skyrimo tvarka: trys ex officio nariai (Aukščiausiojo Teismo pirmasis pirmininkas, Vyriausiojo administracinio teismo pirmininkas ir teisingumo 
ministras), 15 teisejjų iš bendrosios kompetencijos, administracinių ir karinių teismų, Seimo paskirti 4 asmenys, Senato - 2 asmenys ir Prezidento - 1 asmuo.

Beje, kalbant apie šiu institucijų kompetenciją, reikia pasakyti, kad Lietuvos Konstitucijoje paminèta, jog ji pataria Prezidentui dèl teisèjų paskyrimo, paaukštinimo, perkèlimo ir atleidimo iš pareigų. Panašiai ir Lenkijoje Konstitucijos 179 srtaipsnyje teigama, jog Prezidentas skiria teisèjus Nacionalinès Teismų Tarybos pasiūlymu (lenk. na wniosek).

Toliau kalbant apie šią teismų savivaldos instituciją Lietuvoje, būtina paminèti du svarbiausius su tuo susijusius Lietuvos Konstitucinio Teismo nutarimus. Visų pirma, paminètinas 1999 m. gruodžio $21 \mathrm{~d}$. Konstitucinio Teismo nutarimas (Valstybės žinios 1999, Nr. 109-3192). Konstitucinis Teismas šiame nutarime pripažino, kad konstituciniam teismų nepriklausomumo principui prieštaravo Teismų įstatymo nuostatos, pagal kurias buvo nustatyti teisingumo ministro igaliojimai skiriant ir atleidžiant kai kuriuos teisejjus bei skiriant jiems drausmines nuobaudas, jo kompetencija organizuoti teismų finansinị aprūpinimą ir nustatyti privalomąsias teisèjų profesinès kvalifikacijos kèlimo formas, taip pat nuostatos, kuriomis kai kurios teismų administravimo funkcijos buvo nustatytos Teismų departamento prie Teisingumo ministerijos. Po šio Konstitucinio Teismo nutarimo - 2002 metais Lietuvoje vietoj Teismų departamento prie Teisingumo ministerijos buvo sukurta Nacionalinė teismų administracija, kaip nepriklausoma biudžetinė i̊staiga, kuri ir perèmé visas teismų administravimo bei teisminès valdžios savivaldos institucijų aptarnavimo funkcijas, buvusias Teisingumo ministerijos žinioje.

Visgi, didžiausią ịtaką Lietuvos Teisèjų tarybos ịgaliojimams ir sudečiai padarè 2006 m. gegužès 9 d. Konstitucinio Teismo nutarimas (Valstybès žinios 2006, Nr. 51-1894). Pagal jau minètą Teismų ịstatymo 2002 m. sausio 24 dienos redakciją, tuometinę Teismų tarybą sudare 24 nariai, iš kurių (panašiai, kaip yra Lenkijoje) dalis buvo ne teisejjai, t.y. ị jos sudèti ièjo Respublikos Prezidento igaliotas atstovas, Seimo Pirmininko igaliotas atstovas, Seimo Teisès ir teisètvarkos komiteto pirmininkas ar jo pavaduotojas, Seimo Biudžeto ir finansų komiteto pirmininkas ar jo pavaduotojas, teisingumo ministras ar jo įgaliotas viceministras ir finansų ministras ar jo ịgaliotas viceministras. Šią ịstatymo nuostatą, pagal kurią Teismų tarybą, kaip teisminès valdžios savivaldos institucija, turinti igaliojimus patarti Prezidentui dẻl teisèjų skyrimo, sudarè ne tik teisèjai, Konstitucinis Teismas pripažino prieštaraujančia konstituciniam valdžių padalijimo ir teismų nepriklausomumo principui, nes pasak Konstitucinio Teismo, tik profesiniu pagrindu sudaryta speciali teisejjų institucija gali būti atsvara Respublikos Prezidentui - politinio pobūdžio valstybès valdžios institucijai, formuojant teisèjų korpusą.

Be to, minètame nutarime Konstitucinis Teismas ne tik Teismu tarybą paverté Teisejju taryba, bet ir sustiprino jos vaidmenị santykyje su vykdomąja valdžia, konstatavęs, jog be išankstinio jos pritarimo jokia valstybès valdymo 
institucija negali teikti pasiūlymų Vyriausybei dèl asignavimų skyrimo teismams, o Respublikos Prezidentas negali paskirti ar atleisti teisejjo (ar teikti atitinkamo teikimo Seimui), jei Teisejjų taryba tam nepritaré. Beje, šios Konstitucinio Teismo pozicijos, jog Konstitucijos 112 str. 5 dalies terminas ,pataria” turi būti prilygintas terminui „pritaria“ Prezidentui dèl teisejų paskyrimo ar atleidimo iš principo nekritikavo ir Lietuvos teisès mokslininkai (Žr. Butkevičius, Kūris, Šinkūnas, 2011, 162). Tiesa, kai kurie teisės mokslininkai tokio šių skirtingų terminų (kad „pataria“ reiškia „pritaria”) sutapatinimo nors ir nekritikuoja, bet vengia ir sutapatinti (žr. pvz. Beinoravičius, Vainiutè 2017, 576-577).

Visgi, sunku būtų rasti Konstitucija pagrịstą termino „pataria” gramatinès reikšmès pakeitimo pateisinimą. Manytina, jog, jei Konstitucijos būtų norëjęs itvirtinti nuostatą, kad Respublikos Prezidentas negali paskirti ar atleisti teisèjo be Teisèjų tarybos pritarimo, jis taip būtų ir parašęs. Be to, svarbu pastebėti ir tai, kad šiame nutarime Konstitucinis Teismas konstitucionalizavo Visuotinio teisejų susirinkimo, kaip teismų savivaldos institucijos, atsiradimą, kuris, pasak Teismo, tiesiogiai ar per atstovus „turi demokratiškai išrinkti specialios teisèjų institucijos narius, bent absoliučią jų daugumą” (beje, šiame nutarime teigiama, kad „pagal Konstituciją, palyginti nedidelę jų dalị gali paskirti Respublikos Prezidentas ir (arba) teisingumo ministras").

Taigi, po šių Konstitucinio Teismo nutarimų Lietuvos įstatymų leidèjas nustate tokią teismų savivaldos sistemą: Teisejjų taryba, susidedanti iš 23 narių, i kurią pagal pareigas įeina Lietuvos Aukščiausiojo, Apeliacinio ir Vyriausiojo administracinio teismų pirmininkai, o kitus 20 teisejjų kas ketveri metai renka Visuotinis teisèjų susirinkimas. Tiesa, Teismu istatymas numato ir kitas teisejų savivaldos institucijas, kurių nariais gali būti ir ne teisèjai, t.y. Pretendentų ị teisèjus atrankos komisija, Teisèjų etikos ir drausmės komisija, Teisėjų garbės teismas ir Nuolatinè teisèjų veiklos vertinimo komisija.

Tuo tarpu Lenkijoje Nacionalinės Teismų tarybos nariais pagal Konstituciją, kaip jau buvo minta, yra ne tik teisèjai, bet ir teisingumo ministras bei šeši parlamentarai, taigi, i jos sudètị ieina visų trijų valdžių atstovai, nors daugumą sudaro teisejjai (Młynarska-Sobaczewska 2012, 166). Be to, pagal naujai pakeistą Lenkijos Nacionalinès Teismų Tarybos ịstatymą ${ }^{8}$ penkiolika šios Tarybos teisèjų yra skiriami Seimo, o ne renkami Visuotinio teisejjų susirinkimo, kaip, kad buvo anksčiau ir numato Lietuvos Respublikos Teismų ịstatymas. Kaip parodė neseni ìvykiai Lenkijoje, tai, kad nèra konstitucionalizuota Nacionalinès Teismų Tarybos narių (visų pirma, teisėjų) skyrimo tvarka, susiklosčius tam tikrai politinei situacijai, gali palengvinti politikų siekius susilpninti šios institucijos, o kartu ir visos teisminès valdžios nepriklausomybę (Matczak 2018, 3-5).

${ }^{8}$ Ustawa z dnia 12 maja 2011 r. o Krajowej Radzie Sądownictwa. Załącznik do obwieszczenia Marszałka Sejmu Rzeczypospolitej Polskiej w sprawie ogłoszenia jednolitego tekstu ustawy o Krajowej Radzie Sądownictwa z dnia 5 grudnia 2018 r. (poz. 84). 


\section{IŠVADOS}

Nežiūrint ị esminį 1992 m. Lietuvos Respublikos Konstitucijos ir 1997 m. Lenkijos Respublikos Konstitucijos panašumą, galima būtų išskirti šiuos minètų konstitucijų nuostatų, susijusių su teismine valdžia, skirtumus:

1. Lenkijos Konstitucija numato visuomenès dalyvavimą teisingumo vykdyme, o taip pat - karinius teismus, kurie nagrinejja krašto apsaugos ministerijos pareigūnų baudžiamąsias bylas, tuo tarpu Lietuvos Konstitucija nei visuomenès dalyvavimo teisingumo vykdyme, nei karinių teismų nenumato. Be to, Lenkijos Konstitucija numato teisminès valdžios institucijų dvi rūšis: teismai ir tribunolai, ịskaitant ir Konstitucinį Tribunolą. Tuo tarpu Lietuvos Konstitucija tribunolų instituto nenumato.

2. Lietuvos Konstitucija numato dvejopą aukštesnių instancijų teismų teisèjų atleidimo būdą, kai pripažistama, kad jie savo poelgiu pažemino teisejjo vardą: 1) paprastesniu būdu - Aukščiausiojo Teismo teisèją galima atleisti Seimo nutarimu, o Apeliacinio teismo teisèją - Prezidento dekretu arba 2) sudètingesniu būdu - šiems teisèjams pritaikius apkaltos procesą Seime. Tuo tarpu Lenkijos Konstitucija apkaltos proceso atleisti teisejjams nenumato.

3. Lietuvos Konstitucinis Teismas ir Lenkijos Konstitucinis Tribunolas plačiąja prasme priklauso teisminei valdžiai, o šių konstitucinès priežiūros institucijų funkcijos iš esmès yra labai panašios, visgi, pagrindinis skirtumas galètų būti tas, kad ị Lenkijos Konstitucinị Tribunolą dèl teisès aktų abstrakčios konstitucinès kontrolès turi teisę kreiptis daug platesnis subjektų ratas nei ị Lietuvos Konstitucinị Teismą. Iš kitos pusès, Lenkijos Konstitucinis Tribunolas neturi kompetencijos teikti išvadų dẻl pareigūnų veiksmų, kuriems pradètas apkaltos procesas bei dèl rinkimų ịstatymų pažeidimų. Pagaliau, pagal ordinarinę teisę bent vienas Lenkijos Konstitucinio Tribunolo narys ex officio eina ir Lenkijos Vyriausiosios rinkimų komisijos nario pareigas.

4. Nors Lenkijos Konstitucijoje Nacionalinei Teismų Tarybai yra skirtas gana didelis dėmesys, tačiau šiuo metu Lietuvos Teisejjų Tarybos sprendimai turi didesni konstitucinị svorị (nei Lenkijos Nacionalinès Teismų Tarybos), nes jos neigiamas patarimas dèl teisejjų skyrimo ar atleidimo ịpareigoja Lietuvos Respublikos Prezidentą neskirti ar neatleisti teisèjo. Be to, pagal Lietuvos Respublikos Teismu i̊statymą, Lietuvos Teisèjų Tarybos nariais gali būti tik teisèjai, kurių didžioji dalis yra renkama Visuotiniame teisèjų susirinkime, tuo tarpu Lenkijos Teismų Tarybos nariais gali būti ne tik teisejjai, be to, pakeitus ịstatyminị reguliavimą, teisejjai ị šias pareigas Lenkijoje nèra renkami pačios teisminès valdžios, o skiriami politikų. 


\section{BIBLIOGRAFIJA}

\section{MOKSLINE் LITERATŪRA}

Lietuvos konstitucionalizmo istorija: Istoriné Lietuvos Konstitucija. 1387 m.-1566 m.-1791 m.1922 m.-1990 m.. 2016. VU leidykla.

Banaszak, Bogusław. 2006. „The Republic of Poland“. In Constantijn A.J.M. Kortman, Joseph Fleuren, Wim Voermans (eds.). Constitutional law of 10 EU Member states, Wolters Kluwer.

Beinoravičus, Darijus, Vainiute, Milda. 2017. „Teisminès valdžios savivalda ir santykiai su kitomis valdžiomis". In Lietuvos konstitucine teise. MRU.

Butkevičius, Lauras, Kūris, Egidijus, Šinkūnas, Haroldas. 2011. „Teisèjų asmeninio nepriklausomumo garantijos". In Lietuvos teisinès institucijos. VU.

Kalinauskas, Gintaras. 2012. „Lenkijos Respublikos konstitucinè sistema”. In Europos Sajungos valstybiu nariu konstitucinès sistemos. MRU.

Masnevaitè, Elena, Šinkūnas, Haroldas. 2011. „Teismų nepriklausomumo samprata”. In Lietuvos teisinés institucijos. VU vadovèlis.

Matczak, Marcin. 2018. Poland's Constitutional Crisis: Facts and interpretations. The Foundation for Law, Justice and Society in association with the Centre for Socio-Legal Studies and Wolfson College, University of Oxford. Internetine prieiga: https://www.fljs.org/sites/www. fljs.org/files/publications/Poland $\% 27 \mathrm{~s} \% 20$ Constitutional $\% 20$ Crisis $\% 20-\% 20 \mathrm{Facts} \% 20$ and\%20interpretations_0.pdf [žiūrèta: 10.09.2020].

Michalak, Anna. 2016. „Seimo dalyvavimas Konstitucinio Teismo teisejų rinkimuose”. In Lietuvos ir Lenkijos konstitucinés teisès aktualijos: parlamentas. 103-115. VU Leidykla.

Młynarska-Sobaczewska, Anna. 2012. „Wymiar sprawiedliwości”. In Dariusz Górecki (red.). Polskie prawo konstytucyjne w zarysie. 158-167. Warszawa: Lex a Wolters Kluwer business.

Rakowska-Trela, Anna. 2018. „Zasada demokratycznego państwa prawnego a zmiany w prawie wyborczym". Studia Wyborcze 25: 17-30.

Šileikis, Egidijus. 2005. Alternatyvi konstitucinè teisè. TIC.

Šinkūnas, Haroldas, Butkevičius, Lauras. 2011. „Teisminès valdžios nepriklausomumo institucinès garantijos". In Lietuvos teisinès institucijos. VU vadovèlis.

Šinkūnas, Haroldas. 2012. „Ar speciali teisèjų institucija turètų būti sudaroma vien tik iš teisèjų?”. In Nepriklausomos Lietuvos teise: patirtis, dabartis ir ateitis. VU.

Vaičaitis, Vaidotas. 2017. „Status konstytucyjny prezydentów Litwy i Polski”. In Dariusz Górecki (red.). Instytucja prezydenta w polskim i litewskim prawie konstytucyjnym. 195-208. Łódź: Wydawnictwo Universytetu Łódzkiego.

Vaičaitis, Vaidotas. 2019. „Porównanie statusu konstytucyjnego rządu w Polsce i na Litwie w kontekście semiprezydenckiej formy rządów”. In Dariusz Górecki (red.). Wokól rządu w polskim i litewskim prawom konstitucyjnym. Łódź: Wydawnictwo Universytetu Łódzkiego.

Vainiute, Milda. 2012. „XX skyrius. Teisminès valdžios konstituciniai pagrindai”. In Lietuvos Konstituciné Teise. Vadovèlis. MRU.

Vaitiekienè, Elena. 2016. „Teisminès valdžios samprata. Konstituciniai teismų veiklos principai”. In Lyginamoji konstitucinè teisè. Vadovélis. MRU. Registru centras.

Žvaigždinienè, Indrè, Danelienè, Ingrida. 2015. „Aspekty konstytucyjne statusy sądów administracyjnych Litwy oraz ich sędziów”. In Dariusz Górecki (red.). Aktualne problemy polskiego i litewskiego prawa konstytucyjnego. 187-201. Łódź: Wydawnictwo Uniwersytetu Łódzkiego. 


\section{LIETUVOS IR UŽSIENIO VALSTYBIŲ TEISĖS AKTAI}

Lietuvos Respublikos Konstitucija, Valstybès žinios 1992, Nr. 33-1014; Žin. 1996, Nr. 122-2863; Žin. 2002, Nr. 65-2629; Žin. 2003, Nr. 14-540; Žin. 2003, Nr. 32-1316; Žin. 2004, Nr. 1114124; Žin. 2006, Nr. 48-1701; TAR 2019-04-02, k. 2019-05330.

Lietuvos Respublikos Administracinių bylų teisenos įstatymą. Valstybès žinios 1999, Nr. 13-308; TAR 2019-10-01, Nr. 15587.

Lietuvos Respublikos Konstitucinio Teismo įstatymas. Valstybès žinios 1993, Nr. 6-120.

Lietuvos Respublikos Teismų įstatymas. Valstybės žinios 1994, Nr. 46-851; Žin. 2002, Nr. 17-649; Žin. 2006, Nr. 60-2121.

Konstytucja Rzeczypospolitej Polskiej z dnia 2 kwietnia 1997 r. Dz. U., nr 78, poz. 483; z 2006 r., nr 200, poz. 1471; z 2009 r., nr 114, poz. 946 z 2001 r., nr 28, poz. 319.

Prawo o ustroju sądów powszechnych oraz niektórych innych ustaw. Dz. U. z 2015 r., poz. 1224.7.

Prawo o ustroju sądów administracyjnych. Dz. U. z 2019 r., poz. 2167.

Ustawa z dnia 30 listopada 2016 r. o statusie sędziów Trybunału Konstytucyjnego. Dz. U. z 2018 r., poz. 1422.

Kodeks wyborczy z dnia 5 stycznia 2011 r. Dz. U., nr 21, poz. 113; nr 102, poz. 588; nr 147, poz. 881; nr 149, poz. 889; z 2012 r., poz. 139; z 2014 r., poz. 1072.

Ustawa z dnia 12 maja 2011 r. o Krajowej Radzie Sądownictwa. Załącznik do obwieszczenia Marszałka Sejmu Rzeczypospolitej Polskiej w sprawie ogłoszenia jednolitego tekstu ustawy o Krajowej Radzie Sądownictwa z dnia 5 grudnia 2018 r. (poz. 84).

Bundesverfassungsgesetz, Republik Österreich, https://www.ris.bka.gv.at/GeltendeFassung.wxe?A bfrage $=$ Bundesnormen $\&$ Gesetzesnummer $=10000138$.

Grundgesetz für die Bundesrepublik Deutschland, https:/www.gesetze-im-internet.de/gg/ BJNR000010949.html.

Constitución Española, https://www.boe.es/legislacion/documentos/ConstitucionCASTELLANO. pdf.

Constitution de la République française, https://www.conseil-constitutionnel.fr/le-bloc-deconstitutionnalite/texte-integral-de-la-constitution-du-4-octobre-1958-en-vigueur.

Constituição da República Portuguesa, https://dre.pt/web/guest/legislacao-consolidada/-/ lc/34520775/view.

\section{LIETUVOS KONSTITUCINIO TEISMO JURISPRUDENCIJA}

1999 m. gruodžio 21 d. Konstitucinio Teismo nutarimas. Valstybės žinios 1999, Nr. 109-3192.

2003 m. gruodžio 30 d. Konstitucinio Teismo nutarimas. Valstybès žinios 2003, Nr. 124-5643.

2006 m. kovo 28 d. Konstitucinio Teismo nutarimas. Valstybės žinios 2006, Nr. 36-1292.

2006 m. gegužès 9 d. Konstitucinio Teismo nutarimas. Valstybės žinios 2006, Nr. 51-1894.

2006 m. birželio 6 d. Konstitucinio Teismo nutarimas. Valstybės žinios 2006, Nr. 65-2400.

2006 m. lapkričio 27 d. Konstitucinio Teismo nutarimas. Valstybės žinios 2006, Nr. 130-4910. 